\title{
Physical aspects of coral reef lagoon sediments in relation to detritus processing and primary production
}

\author{
R. W. Johnstone ${ }^{1, *}$, K. Koop ${ }^{2}$, A. W. D. Larkum ${ }^{1}$ \\ ${ }^{1}$ School of Biological Sciences, A12, University of Sydney, Sydney 2006, Australia \\ ${ }^{2}$ Zoology Department, University of Stockholm, S-10691 Stockholm, Sweden
}

\begin{abstract}
Physico-chemical analysis of sediments showed there to be 4 main sediment types in One Tree Lagoon (Southern Great Barrier Reef) ranging from coarse sand to very fine sand. These sediments showed characteristic depth profiles of dissolved oxygen and $E_{h}$. Oxygen was depleted within the top 5 to $10 \mathrm{~mm}$ of the sediment and redox values were correspondingly low. These values showed seasonal differences. The sediments were generally oxidized in winter $\left(E_{h}\right.$ values $\left.\geq-38 \mathrm{mV}\right)$ but reduced in summer $\left(E_{h} \leq-100 \mathrm{mV}\right.$ ). Sediment concentrations of total organic carbon (TOC) and total nitrogen (TN) were typically 0.28 and $0.06 \%$ respectively with no significant difference between seasons. A significant difference was observed, however, for TOC levels between sediment types with highest concentrations observed in the very fine sand $(0.29 \pm 0.005 \%)$. Mean values for community primary production $(\mathrm{P})$ and net community production $\left(\mathrm{P}_{n}\right)$ over all seasons were higher in the coarse sand $(\mathrm{P}=$ $\left.0.44 \mathrm{gC} \mathrm{m}^{-2} \mathrm{~d}^{-1} ; \mathrm{P}_{\mathrm{n}}=0.05 \mathrm{gC} \mathrm{m}^{-2} \mathrm{~d}^{-1}\right)$ than in the very fine sand $\left(\mathrm{P}=0.26 \mathrm{gC} \mathrm{m}^{-2} \mathrm{~d}^{-1} ; \mathrm{P}_{\mathrm{n}}=-0.003 \mathrm{gC}\right.$ $\mathrm{m}^{-2} \mathrm{~d}^{-1}$ ). The coarse sand had a $P / R$ ratio $\geq 1$ whilst the very fine sand had $P / R$ ratios of $\geq 1$ summer but $\leq 1$ in winter. Community respiration values $(\mathrm{R})$ were higher in winter than in summer $(\mathrm{R}=0.29 \pm 0.03$ and $0.24 \pm 0.02 \mathrm{gC} \mathrm{m}^{-2} \mathrm{~d}^{-1}$ respectively). Bacterial abundance in sediments was 2 to 3 times higher in winter in both the very fine and coarse sediment types. Sediment community production was low compared to detrital input and since any net accumulation of $\mathrm{C}$ and $\mathrm{N}$ in sediments is likely to be low, this production is probably consumed by sediment grazers
\end{abstract}

\section{INTRODUCTION}

For those interested in coral reef ecosystems the extremely diverse communities and the tight coupling of nutrient and energy fluxes present a great challenge in terms of understanding their trophodynamics. Numerous studies have been conducted to quantify the flow of carbon through coral reef ecosystems. The majority of such studies of community metabolism on coral reefs have tended to concentrate on the more active zones such as the reef crest, coral/aigal reef flat, reef slopes and areas of hard substratum. The resulting values in the literature for both gross community primary production $(\mathrm{P})$ and respiration $(\mathrm{R})$ range from 4 to $24 \mathrm{gC} \mathrm{m}^{-2} \mathrm{~d}^{-1}$ (e.g. see review by Kinsey 1983). As suggested by Kinsey (1983), one consequence of these types of studies is that values obtained from these

\footnotetext{
- Present address: Zoology Department, University of Stockholm, S-10691 Stockholm, Sweden
}

zones are sometimes misquoted as being characteristic of the activity of coral reefs. Studies which have examined specific biotopes within these larger zones (Smith 1973, Kinsey 1979, Vooren 1981, Sorokin 1982 and others) have certainly shown there to be considerable variation in community metabolism which is not apparent in the broader studies. Coral reef lagoons and their sand sediments have received relatively little attention.

Work dealing specifically with coral reef sands has indicated that they have fairly low rates of community production, ranging from 0.6 to $2.7 \mathrm{gC} \mathrm{m}^{-2} \mathrm{~d}^{-1}$, and a correspondingly low community respiration ranging from 1.4 to $2.4 \mathrm{gC} \mathrm{m}^{-2} \mathrm{~d}^{-1}$ (Sournia 1976, Kinsey 1977 , 1979, Sorokin 1982). P/R ratios in the literature range from 0.6 to 1.1 (Kinsey 1983). The sandy bottoms of lagoons are not only the site of primary production from an active surface layer of benthic mircoalgae but are also the site for the deposition of much of the detritus generated at highly productive sites such as the reef 
crest and reef flat which is subsequently washed into the lagoon. At One Tree Reef, the extent of such detrital input is large: ca $1.5 \mathrm{gC} \mathrm{m}^{-2} \mathrm{~d}^{-1}$ (Koop \& Larkum 1987). Little is known, however, of the processes by which this organic matter is turned over and which heterotrophic organisms it supports.

The present study was conducted over a $3 \frac{1}{2}$ yr period from winter 1984 to summer 1987. The study characterizes the sediments in One Tree Lagoon, Southern Great Barrier Reef, in terms of physico-chemical parameters such as grain size distribution, redox and oxygen profiles as well as total organic carbon and total nitrogen content. This information is used in conjunction with measurements of community metabolism and bacterial biomass to estimate the significance of sediment community production in different seasons both within and between the sediment types of the lagoon ecosystem.

\section{MATERIALS AND METHODS}

Sediment grain size distribution and site description. One Tree Reef is remote to terrestrial effects, lying ca $95 \mathrm{~km}$ from the Australian mainland. The sediments in One Tree lagoon are comprised almost entirely of $\mathrm{CaCO}_{3}$ derived from the surrounding coral matrix. There are no macroalgae on sediments in the lagoon proper but various species comprise the epilithic algal communities on the reef flat and back-reef areas. Benthic macrofauna include a variety of deposit-feeding organisms such as sea cucumbers (e.g. Holothuria atra, H. scabra, Stichopus chloronotus), gastropods (e.g. Rhinoclavis aspera, Tellina robusta), and different crustacea (e.g. Callianassa sp.). A number of fish species also feed in and on the lagoon sediments and these include benthic dwellers, such as the tommy fish (e.g. Limnichthys fasciatus) and gobie fish (e.g. Amblyeleotris fasciata). Whilst there have been no studies of sediment meiofauna at One Tree Reef, studies conducted elsewhere (e.g. Alongi 1986, Hansen et al. 1987) show there to generally be a well-developed but variable meiofaunal community within coral reef sediments.

To determine grain size distribution 3 replicate cores (15 $\mathrm{cm}$ deep by $5 \mathrm{~cm}$ diameter) were taken by hand using SCUBA at 12 sites along each of 3 transects across the main lagoon of One Tree Reef (Fig. 1a, b). The transects all began and finished in the shallow sand areas ca 200 to $300 \mathrm{~m}$ behind the reef flat on opposite sides of the main lagoon. Mean water depth at low tide in these shallow areas is ca $1 \mathrm{~m}$ and there is little to no wave action. Also, currents of ca $20 \mathrm{~cm} \mathrm{~s}^{-1}$ can occur here depending on tidal conditions (Frith 1983). Water depth in the centre of the lagoon where the transects intersected is typically 5 to $7 \mathrm{~m}$ and currents are always $<10 \mathrm{~cm} \mathrm{~s}^{-1}$ (Frith 1983). The sampling sites were placed as evenly apart as possible a

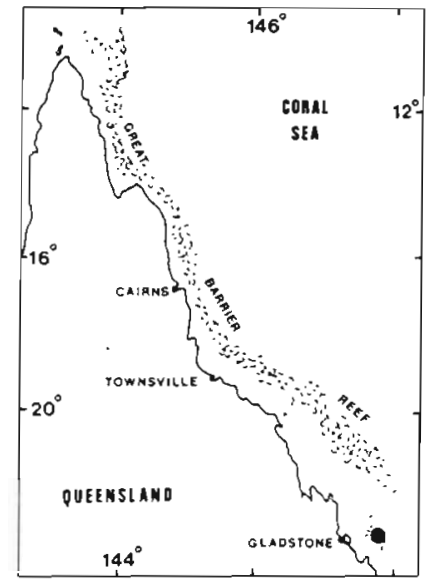

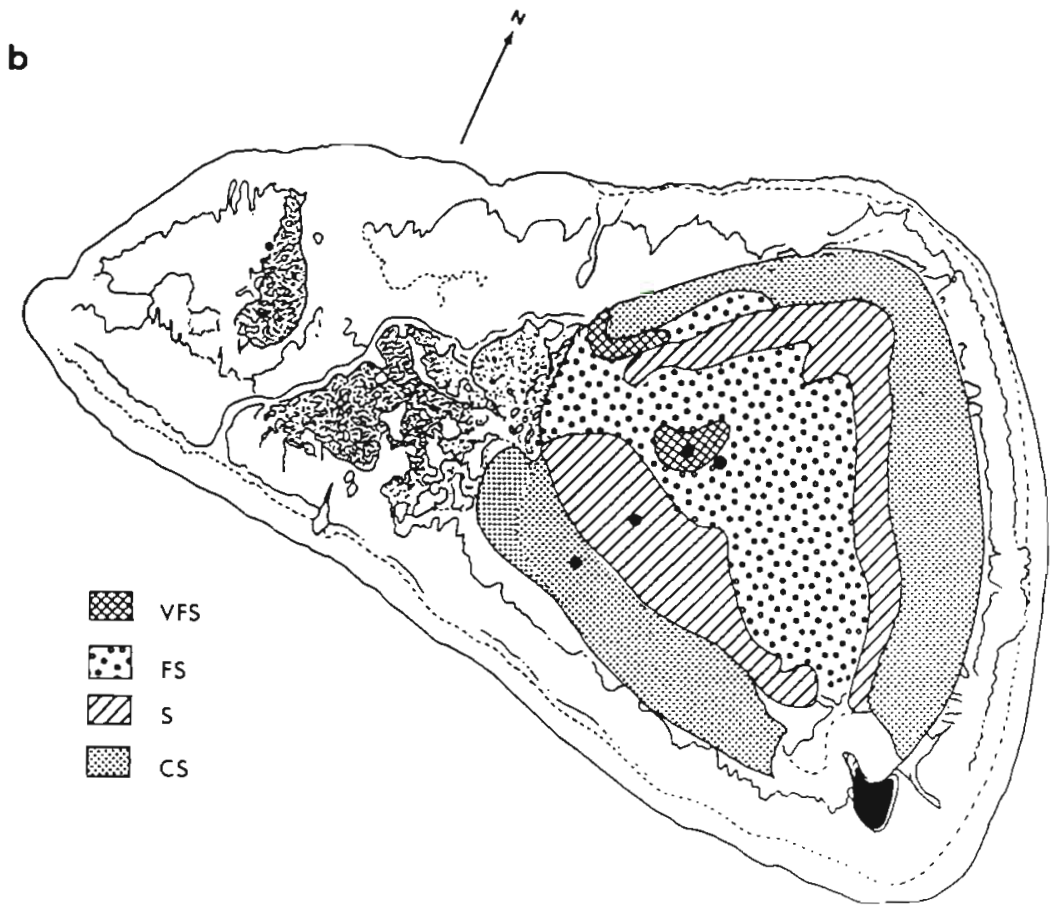

Fig. 1. (a) Great Barrier Reef showing the location of One Tree Reef at the southern end. (b) One Tree Reef showing the sampling transects and distribution of the main sediment types identified within the main lagoon. The 4 positions marked are the experimental sites used for community metabolism studies 
along the transects except where they occurred either directly on top of a patch reef or within $1 \mathrm{~m}$ distance of it. When this occurred the sample was taken from the nearest body of sediment along the transect. In addition, random samples were taken in smaller areas to define sediment boundaries. After collection, each core was partially air-dried and then cut into $1 \mathrm{~cm}$ slices at 0 , $4.5,9.5$ and $14.5 \mathrm{~cm}$ depth. The individual slices were dried at $60^{\circ} \mathrm{C}$ to constant weight and dry sieved through a set of 7 sieves with mesh sizes of $0.063 \mathrm{~mm}$ $(-4 \phi)$ to $2.000 \mathrm{~mm}(1 \phi)$. The weight of each size fraction was taken and its percentage by weight of the whole sample calculated.

Total organic carbon and nitrogen content of sediments. During summer and winter 1984 and 1985 , 4 replicate cores $(5 \mathrm{~cm}$ diameter $\times 20 \mathrm{~cm}$ deep) were taken as above at each of the main sediment sites. Four $1 \mathrm{~cm}$ thick sections were then taken from each core at $0,5,10$, and $15 \mathrm{~cm}$ depth and oven-dried at $60^{\circ} \mathrm{C}$ to constant weight. Half of each section was used for total organic carbon measurements, and the other half for total nitrogen analysis. Prior to analysis, all samples were held in a desiccator at $-4^{\circ} \mathrm{C}$ for transport to the laboratory and analyses were conducted within $14 \mathrm{~d}$ of sample collection.

Samples for total organic carbon (TOC) were analyzed according to the method of Sandstrom et al. (1986). The sediment was first ground to a fine powder and then dissolved in $5 \% \mathrm{v} / \mathrm{v}$ phosphoric acid to remove inorganic carbon $\left(\mathrm{CaCO}_{3}\right)$. The resulting solution was then purged with oxygen to remove $\mathrm{CO}_{2}$ and anaylzed for organic carbon on a Beckman 915B total carbon analyzer.

Total nitrogen (TN) was determined on a Heraeus Elemental Analyzer, CHN-Rapid (W. C. Heraeus GmbH, Hanau, FRG) using 4 replicate subsamples of $50 \mathrm{mg}$ from each sediment section.

Sediment $\mathbf{p H}$ and $\mathbf{E}_{\mathbf{h}}$. Eight replicate $\mathrm{pH}$ and $\mathrm{E}_{\mathbf{h}}$ measurements were carried out on interstitial water samples taken by means of in situ perspex diffusion chambers which were placed at $0.5,2.5,5,10$ and $15 \mathrm{~cm}$ depth in the respective sediment types. The chambers were inserted laterally into the sediment through slits in the wall of plastic wells at each study site. This arrangement is described in detail elsewhere (Johnstone et al. 1988).

All samples were immediately placed on ice after collection and both $\mathrm{pH}$ and $\mathrm{E}_{\mathrm{h}}$ were measured in the boat anchored on site using a field $\mathrm{pH} / \mathrm{mV}$ meter. Redox values were calibrated against the standard hydrogen electrode potential.

In addition to interstitial water, $\mathrm{E}_{\mathrm{h}}$ and $\mathrm{pH}$ were also measured in water taken from within $5 \mathrm{~cm}$ above the sediment at each site with a $50 \mathrm{ml}$ syringe. These samples were taken at the same time as interstitial samples and were subsequently treated in the same manner.

Measurements were conducted during winter and summer 1986.

Interstitial oxygen measurements. Interstitial oxygen concentrations were measured each summer and winter using a polarographic oxygen sensor which consisted of a platinum electrode $(0.5 \mathrm{~mm}$ diameter $)$ and a $\mathrm{Ag} / \mathrm{AgCl}$ reference electrode connected to a polarizing voltage and a microammeter. The basic principles of how this system works are described in detail by Revsbech \& Jörgensen (1986). The sensor was calibrated against a Y.S.I. Clark-style oxygen electrode by bubbling different amounts of nitrogen gas through seawater to bring it to known oxygen concentrations. The calibration was repeated between replicates as a check against poisoning of the electrode by sediment contaminants such as sulfide.

Using this system, interstitial oxygen was measured by taking 4 replicate sediment cores and pushing the platinum electrode directly into the sediment with a calibrated vernier. This gave a depth resolution of $\pm 0.1 \mathrm{~mm}$.

Interstitial oxygen measurements were carried out within $2 \mathrm{~h}$ of redox measurements using sediment cores taken by hand (SCUBA) from the same area of sediment used for redox measurements.

Community production measurements. Community primary production was determined by measuring the change in dissolved oxygen concentration in water enclosed by perspex domes placed haphazardly over the sediment at each study site. The domes were hemispherical with a basal area of $640 \mathrm{~cm}^{2}$ and a volume of $36 \mathrm{l}$ (see also Johnstone et al. 1988). Oxygen concentration was measured in situ with a 'Clark' style oxygen electrode which was pushed through a selfsealing sampling port on the side of each dome. The water within domes was stirred gently by means of a hand-held impeller until a steady oxygen reading was obtained. Readings were taken every $2 \mathrm{~h}$ for $24 \mathrm{~h}$ in each of 4 domes placed randomly at each sediment site. This was repeated in summer and winter for $3 \mathrm{yr}$ commencing in July 1984 in coarse and very fine sediments.

Community net primary production rates $\left(\mathrm{P}_{\mathrm{n}}\right.$; $\mathrm{gC} \mathrm{m}^{-2} \mathrm{~d}^{-1}$ ) were calculated from the oxygen production curves obtained from each dome using the method of Kinsey (1978). This method uses the following equation:

$$
P_{n}=(P \alpha)-(R \beta)
$$

where $\alpha=$ hours of daylight; $\beta=24-\alpha ; P=$ rate of carbon exchange in the light $\left(\mathrm{gC} \mathrm{m}^{-2} \mathrm{~d}^{-1}\right) ; \mathrm{R}=$ rate of carbon exchange in the dark $\left(\mathrm{gC} \mathrm{m}^{-2} \mathrm{~d}^{-1}\right)$. Hourly oxygen production was calculated from the mean 
difference in the oxygen concentration of entrapped dome water over each sampling interval. To convert oxygen data to grams carbon fixed, respiratory and photosynthesis quotients of 1.0 were used (Kinsey 1979).

Chlorophyll and phaeopigment determinations. Six replicate cores (12 mm diameter $\times 15 \mathrm{~mm}$ deep; $2 \mathrm{~cm}^{3}$ vol.) were taken randomly at each sediment site. Each core was dispensed into a $10 \mathrm{ml}$ centrifuge tube and thoroughly mixed on a Vortex mixer $(5 \mathrm{~min})$ with $5 \mathrm{ml}$ of $90 \%$ acetone in distilled water. Glass beads were added to the sediment mixture to facilitate the grinding up of the softer carbonate fragments. The samples were extracted at $0^{\circ} \mathrm{C}$ for $12 \mathrm{~h}$ and then centrifuged at $3000 \mathrm{rpm}$ for $5 \mathrm{~min}$. Total chlorophyll $(a, b$, and $c)$ and phaeopigment content was calculated using the method of Parsons et al. (1984).

Bacterial abundance in lagoon sediments. Bacterial numbers in sediments were determined by direct counts using a modified version of the acridine orange method outlined by Hobbie et al. (1977). Ten replicate cores were randomly collected from each sediment site using the same method as for chlorophyll cores, and each of these were immediately dissolved in $10 \mathrm{ml}$ of $0.1 \mathrm{M}$ glacial acetic acid to remove calcium carbonate. After bubbling ceased, the solution was homogenized in a Sorvall Omnimix for $60 \mathrm{~s}$ and three $1 \mathrm{ml}$ subsam- ples taken. These aliquots were diluted with freshly prepared filtered seawater ( $0.2 \mu \mathrm{m}$ Nuclepore filter) to obtain an optimum counting range of ca 40 cells per field. This solution $(5 \mathrm{ml})$ was then incubated with $100 \mu \mathrm{l}$ of acridine orange solution for $4 \mathrm{~min}(1.0 \mathrm{mg}$ acridine orange $\mathrm{l}^{-1}$ ). The final solution was passed through a $0.2 \mu \mathrm{m}, 24 \mathrm{~mm}$ diameter Nuclepore filter; pre-stained with Irgalan black dye solution to reduce background fluorescence $(100 \mathrm{mg}$ Irgalan black in $200 \mathrm{ml}$ of filtered $2 \%$ acetic acid). The bacteria were counted, 10 fields per slide, with a fluorescence microscope. Normally each filter was counted twice and if the 2 counts differed by $>5 \%$, the filter was counted a third time and the mean taken of the 3 counts.

\section{RESULTS}

\section{Grain size analysis}

From the grain size analysis it was possible to define 4 categories of sediment across the main lagoon of One Tree Reef. The categories were established on the basis that each had $\geq 40 \%$ of its grain components within a given size range and were named according to the categories of Gray (1981). Fig. 2 shows distribution histograms representative of each sediment type and the

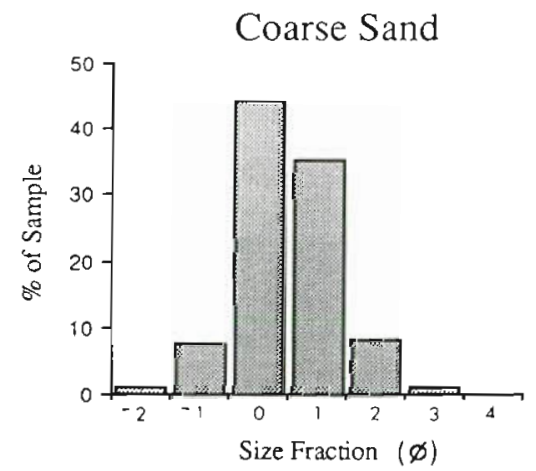

Fine Sand

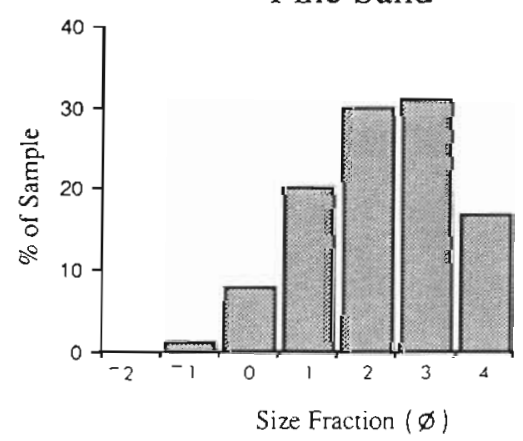

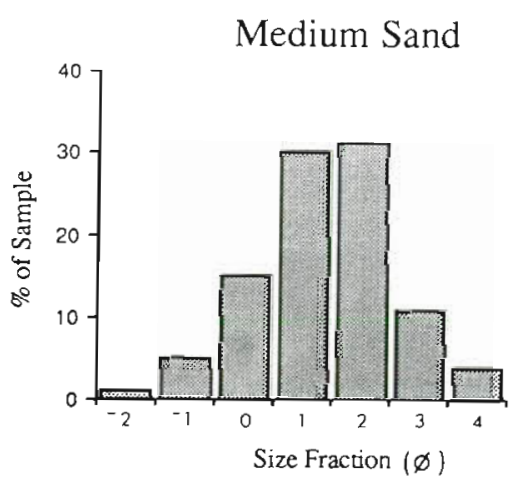

Very Fine Sand

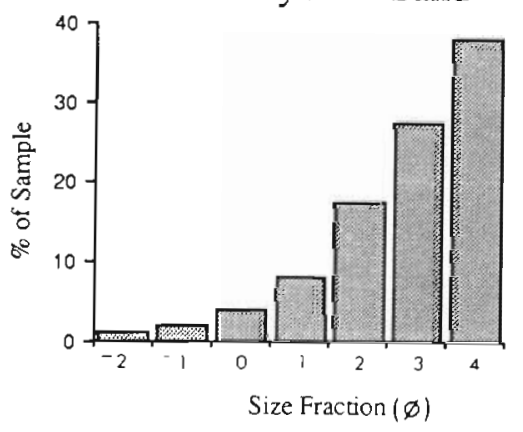

Fig. 2. Characteristic grain size distributions for the main sediment types in One Tree Lagoon. The finest sediment is very fine sand (VFS), followed by fine sand (FS), medium sand (MS) and coarse sand (CS). These categories are defined by the following size ranges: VFS: $\leq 0.125 \mathrm{~mm}$; FS: between 0.125 and $0.250 \mathrm{~mm}$; MS: between 0.250 and $0.5 \mathrm{~mm}$; and CS: $\geq 0.5 \mathrm{~mm}$. Values on the $\mathrm{x}$-axis are phi units 
distribution of sediments in the lagoon is presented in Fig. 1b.

Coarse sand (CS) accounted for ca $1.25 \mathrm{~km}^{2}$ with medium sand (MS), fine sand (FS) and very fine sand (VFS) having areas of $0.78,0.92$ and $0.08 \mathrm{~km}^{2}$ respectively. These areas represent $41.0,25.5,30.2$ and $3.4 \%$ respectively of the total lagoon area (ca $3.1 \mathrm{~km}^{2}$ ).

\section{Sediment $\mathrm{pH}$ and $\mathrm{E}_{\mathrm{h}}$}

Results from interstitial water analyses showed that the sediment types defined by grain size distribution exhibited different patterns for $E_{h}$, but not for $p H$ (Table 1). Summer $\mathrm{pH}$ values $(\overline{\mathrm{x}}=7.82)$ were significantly higher than winter values $(\overline{\mathrm{x}}=7.58$ ) (ANOVA: $0.01<\mathrm{p}<0.05)$. Mean sediment $\mathrm{pH}$ in winter was 7.58 compared to 7.82 in summer.

Redox $\left(E_{h}\right)$ values showed a clear seasonal difference (Fig. 3). There was a significant change from largely oxidative sediment $E_{h}$ values in winter (up to $+180 \mathrm{mV}$ ) to entirely reducing sediments in summer (down to $-175 \mathrm{mV}$ ). The interactions likely to be responsible for this are discussed later. Redox potentials in the water column immediately above the sediment were always $\geq 180 \mathrm{mV}$ over the entire year In winter, only the coarse sand differed significantly from the other sediment types and in summer, no significant differences were detected. Reliable redox data could not be collected for fine sediment in summer.

\section{Total organic carbon and total nitrogen content}

Overall, total organic carbon (TOC) varied remarkably little (Table 2). The mean TOC value for all sediment types and sediment depths was $0.275 \% \mathrm{w} / \mathrm{w}$ in summer, and $0.280 \%$ in winter. Analysis of variance $(p=0.05)$ showed no significant difference between summer and winter results for sediment type or depth within sediments. Within seasons, however, there were significant differences between sediment types and between sediment depths. As is clear from Table 2, TOC decreased slightly but consistently with increase in depth.

Mean values for each sediment type for total nitrogen were 0.062 (CS), 0.054 (MS), 0.053 (FS), and $0.057 \% \mathrm{w} / \mathrm{w}$ (VFS) (Table 3). There were no significant differences between summer and winter (analysis of variance; $\mathrm{p}=0.05$ ), with means of 0.057 and $0.060 \%$ $w / w$ total nitrogen respectively. Samples from different sediment depths and different years also showed no significant difference.

Carbon to nitrogen ( $\mathrm{C}: \mathrm{N}$ ) ratios calculated from the above data again showed no significant difference

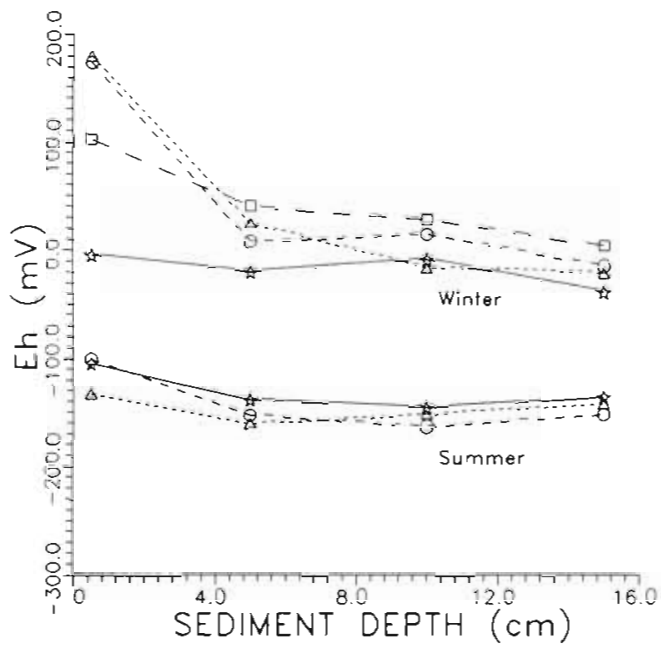

Fig. 3. Interstitial redox potentials $\left(E_{h}\right)$ in the main sediment types in One Tree Lagoon for summer and winter $E_{h}$ profiles were not significantly different within seasons except at $0.5 \mathrm{~cm}$ depth in coarse sand in winter. Seasonal differences were significant. (..) Coarse sand; (0) medium sand; (0) fine sand; (o) very fine sand

between winter and summer results or between depths within sediment types. For both seasons, however, coarse sand (CS) was significantly lower than the other 3 sediment types with a mean of 4.5 compared to 4.9 (MS), 5.2 (FS), and 5.0 (VFS).

\section{Sediment oxygen levels}

The majority of sediments showed no measurable oxygen concentration below $5 \mathrm{~mm}$ depth, and the gradient of the concentration profile became steeper as the sediment type changed from coarse to fine. The coarse and very fine sediments represented the extremes in oxygen depth profiles, with the other 2 sediments showing profiles between these. Seasonally there was a slight increase in the depth of oxygen penetration in winter for both the coarse and very fine sediments (Fig. 4).

\section{Community production}

Community production experiments showed significantly higher community photosynthesis (P) and community respiration $(R)$ in the coarse sand than the very fine sand. Between seasons, there was an increase in community primary production in summer in the coarse sand but this was not observed in the very fine sand. Also, there was a difference in primary production values and photosynthesis to respiration ratios between some years within the 2 sediment types studied (Fig. 5a, b) but these were not significant. The data were first analyzed with a 3-way analysis of variance 
Table 1. Values for $E_{h_{2}}$ and $\mathrm{pH}$ in porewaters from the main sediment types in One Tree Lagoon: CS, coarse sand $\mathrm{MS}$, medium sand; FS, fine sand; VFS, very fine sand. $E_{h}$ values are in $\mathrm{mV}$, and numbers in brackets are $95 \%$ confidence limits

\begin{tabular}{|c|c|c|c|c|c|c|c|c|}
\hline \multirow{2}{*}{$\begin{array}{l}\text { Depth } \\
\text { (cm) }\end{array}$} & \multicolumn{2}{|c|}{$\mathrm{CS}$} & \multicolumn{2}{|c|}{ MS } & \multicolumn{2}{|c|}{ FS } & \multicolumn{2}{|c|}{ VFS } \\
\hline & $\mathrm{E}_{\mathrm{h}}$ & $\mathrm{pH}$ & $E_{h}$ & $\mathrm{pH}$ & $E_{h}$ & $\mathrm{pH}$ & $E_{h}$ & $\mathrm{pH}$ \\
\hline \multicolumn{9}{|c|}{ Summer } \\
\hline \multirow[t]{2}{*}{0.5} & -104 & 7.83 & -132 & 7.94 & $L^{a}$ & 7.83 & -100 & 7.92 \\
\hline & $(29.4)$ & $(0.24)$ & $(21.6)$ & $(0.20)$ & - & $(0.08)$ & $(92.0)$ & $(0.16)$ \\
\hline \multirow[t]{2}{*}{5.0} & -137 & 7.71 & -159 & 7.83 & - & 7.82 & -151 & 7.80 \\
\hline & $(21.6)$ & $(0.08)$ & $(38.9)$ & $(0.10)$ & 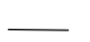 & $(0.16)$ & $(23.7)$ & $(0.16)$ \\
\hline \multirow[t]{2}{*}{10.0} & -144 & 7.73 & -151 & 7.84 & - & 7.91 & -162 & 7.98 \\
\hline & $(12.7)$ & $(0.16)$ & $(34.0)$ & $(0.24)$ & $\longrightarrow$ & $(0.30)$ & $(9.4)$ & $(0.14)$ \\
\hline \multirow[t]{2}{*}{15.0} & -134 & 7.70 & -140 & 7.81 & - & 7.92 & -150 & 7.98 \\
\hline & $(15.6)$ & $(0.10)$ & $(47.6)$ & $(0.16)$ & - & $(0.22)$ & (18.3) & $(0.04)$ \\
\hline \multicolumn{9}{|l|}{ Winter } \\
\hline \multirow[t]{2}{*}{0.5} & -4 & 7.53 & +180 & 7.64 & +130 & 7.60 & +174 & 7.67 \\
\hline & $(21.8)$ & $(0.14)$ & $(88.5)$ & $(0.16)$ & $(45.7)$ & $(0.16)$ & $(60.0)$ & $(0.12)$ \\
\hline \multirow[t]{2}{*}{5.0} & -20 & 7.53 & +25 & 7.49 & +40 & 7.58 & +8 & 7.59 \\
\hline & (18.9) & $(0.10)$ & $(23.7)$ & $(0.22)$ & $(48.0)$ & $(0.12)$ & $(61.5)$ & $(0.12)$ \\
\hline \multirow[t]{2}{*}{10.0} & -8 & 7.54 & -15 & 7.50 & +29 & 7.56 & -16 & 7.76 \\
\hline & $(12.6)$ & $(0.08)$ & $(22.9)$ & $(0.16)$ & $(44.7)$ & $(0.22)$ & $(17.0)$ & $(0.10)$ \\
\hline \multirow[t]{2}{*}{15.0} & -38 & 7.50 & -20 & 7.43 & +4 & 7.64 & -14 & 7.56 \\
\hline & $(15.0)$ & $(0.08)$ & (11.9) & $(0.14)$ & $(15.7)$ & $(0.22)$ & $(18.0)$ & $(0.16)$ \\
\hline
\end{tabular}

(Table 4) and then subsequently analyzed within years, sediment types and seasons.

In the coarse sand, a considerable difference was observed for photosynthesis values (P) between summer 1987 and summer of the previous $2 \mathrm{yr}$ but values

Table 2. Mean values for total organic carbon content in the main sediment types in One Tree Lagoon: CS, coarse sand; MS, medium sand; FS, fine sand; VFS, very fine sand. Values given are percentage by dry weight; values in parentheses are standard deviations

\begin{tabular}{|ccccc|}
\hline $\begin{array}{c}\text { Depth } \\
(\mathrm{cm})\end{array}$ & CS & MS & FS & VFS \\
\hline $\begin{array}{ccccc}\text { Summer } \\
0\end{array}$ & 0.291 & 0.273 & 0.292 & 0.292 \\
& $(0.014)$ & $(0.016)$ & $(0.021)$ & $(0.028)$ \\
5 & 0.265 & 0.256 & 0.280 & 0.287 \\
& $(0.017)$ & $(0.025)$ & $(0.009)$ & $(0.009)$ \\
10 & 0.278 & 0.265 & 0.266 & 0.281 \\
& $(0.012)$ & $(0.003)$ & $(0.014)$ & $(0.011)$ \\
15 & 0.259 & 0.265 & 0.271 & 0.280 \\
& $(0.009)$ & $(0.011)$ & $(0.016)$ & $(0.005)$ \\
Winter & & & & \\
0 & 0.287 & 0.266 & 0.296 & 0.287 \\
& $(0.018)$ & $(0.012)$ & $(0.011)$ & $(0.013)$ \\
5 & 0.262 & 0.260 & 0.287 & 0.273 \\
& $(0.020)$ & $(0.017)$ & $(0.008)$ & $(0.016)$ \\
10 & 0.270 & 0.258 & 0.260 & 0.285 \\
& $(0.015)$ & $(0.010)$ & $(0.022)$ & $(0.011)$ \\
15 & 0.264 & 0.246 & 0.262 & 0.283 \\
& $(0.013)$ & $(0.021)$ & $(0.012)$ & $(0.009)$ \\
& & & & \\
\hline
\end{tabular}

for $R$ and $P / R$ ratios were not significantly different from year to year. By comparison the very fine sand showed a difference in P/R values for summer 1986 compared to the other 2 summers sampled, but there was no significant difference between yearly values for

Table 3. Mean values for total nitrogen content in the main sediment types in One Tree Lagoon: CS, coarse sand; MS medium sand; FS, fine sand; VFS, very fine sand. Values given are percentage by dry weight; values in parentheses are standard deviations

\begin{tabular}{|ccccc|}
\hline $\begin{array}{c}\text { Depth } \\
\text { (cm) }\end{array}$ & CS & Sediment type & VFS \\
\hline Summer & & & $F S$ & \\
0 & 0.061 & 0.054 & 0.054 & 0.064 \\
& $(0.003)$ & $(0.002)$ & $(0.004)$ & $(0.006)$ \\
5 & 0.058 & 0.051 & 0.056 & 0.059 \\
& $(0.004)$ & $(0.002)$ & $(0.004)$ & $(0.013)$ \\
10 & 0.058 & 0.057 & 0.056 & 0.065 \\
& $(0.006)$ & $(0.006)$ & $(0.004)$ & $(0.012)$ \\
15 & 0.059 & 0.054 & 0.054 & 0.061 \\
& $(0.005)$ & $(0.008)$ & $(0.003)$ & $(0.014)$ \\
Winter & & & & \\
0 & 0.058 & 0.056 & 0.058 & 0.062 \\
& $(0.006)$ & $(0.010)$ & $(0.007)$ & $(0.003)$ \\
5 & 0.059 & 0.053 & 0.058 & 0.060 \\
& $(0.003)$ & $(0.006)$ & $(0.011)$ & $(0.004)$ \\
10 & 0.062 & 0.053 & 0.052 & 0.058 \\
& $(0.008)$ & $(0.005)$ & $(0.009)$ & $(0.008)$ \\
15 & 0.059 & 0.051 & 0.053 & 0.057 \\
& $(0.002)$ & $(0.006)$ & $(0.005)$ & $(0.011)$ \\
& & & & \\
\hline
\end{tabular}


P or R (Fig. 5a, b). As for coarse sand, there was no such difference in winter values for $P, R$ or $P / R$ in the very fine sand.

In experiments where production measurements were made on 2 consecutive days within sediment types, there were no significant differences between the mean values obtained from each. Logistically it was not possible to run an experiment with more than 4 domes at once and so spatial variation at each site remains poorly defined. Because the consecutive experiments, which were more than $30 \mathrm{~m}$ apart, were not significantly different, however, it seems unlikely that the variation within each sediment type is very great.

Within seasons, the coarse sand gave significantly higher values for $P$ and $R$ in summer than the very fine sand ( $F=35.14$ and 60.13 respectively). There was no significant difference, however, between $P / R$ values for the 2 sediment types with both being autotrophic
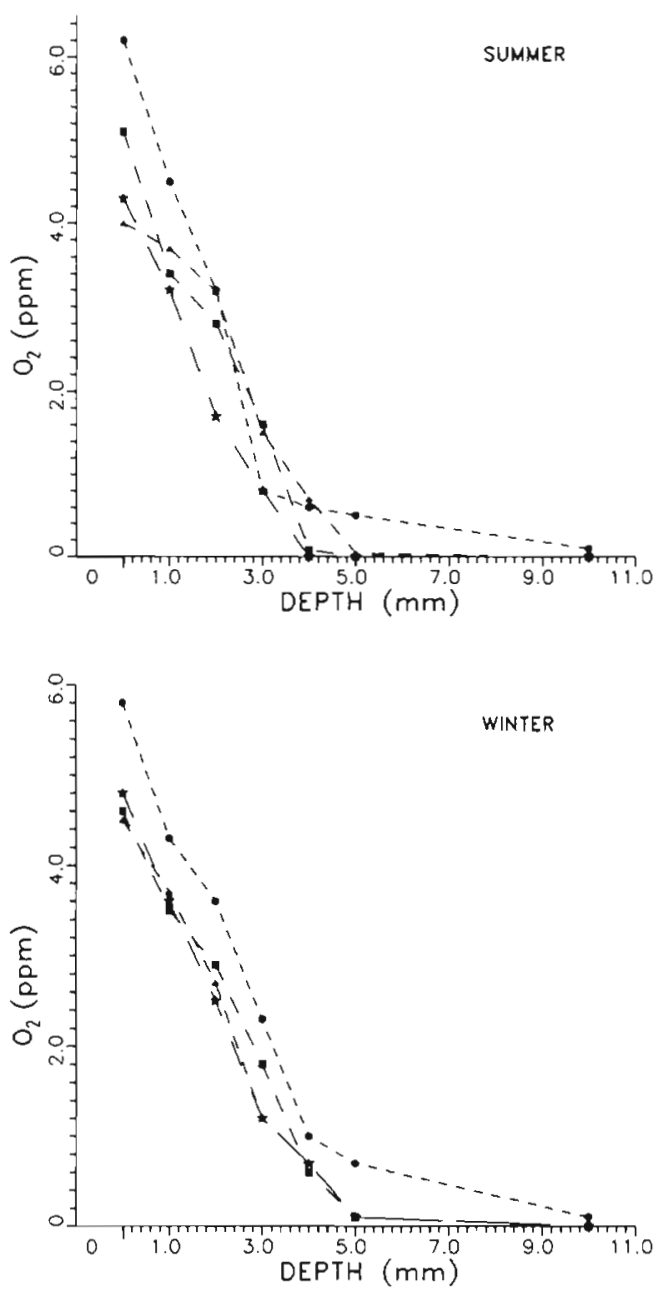

Fig. 4. Concentration of dissolved oxygen at different depths in the main sediment types at One Tree Lagoon for summer and winter. ( $\bullet$ ) Coarse sand; ( $₫$ ) medium sand; ( $\bullet$ ) fine sand; ( ) very fine sand
$(P / R \geq 1)$. In winter, the coarse sand gave higher values for $P, R$ and $P / R$ than the very fine sand $(F=24.04,8.85$, and 9.37 respectively), and, as in summer, it was autotrophic whereas the very fine sand was heterotrophic $(\mathrm{P} / \mathrm{R}<1)$.

As $R$ represents respiration for the whole $24 \mathrm{~h}$ period, the net community production $\left(\mathrm{P}_{n}\right)$ was determined by subtraction of $\mathrm{R}$ from $\mathrm{P}$. When examined using ANOVA $(p=0.05)$ it was found that within sediment types there was no significant difference in winter $P_{n}$ values from year to year. In the coarse sand, summer $P_{n}$ values were lower in 1986 than in the other $2 \mathrm{yr}$ and in the very fine sand, $P_{n}$ values were lower in 1987 than in the previous 2 yr. Within sediment types there was a significant difference between summer and winter values for $P_{n}$ $(F=24.10$ (CS) and 31.96 (VFS); df $=1 / 22$ ) with both sediment types having higher values in summer than in winter.

When compared within seasons, there was a significant difference between $P_{n}$ values from coarse sand and very fine sand in summer $(F=5.6$; $\mathrm{df}=1 / 22)$ with coarse sand having a higher mean of $0.12 \pm 0.05 \mathrm{gC}$ $\mathrm{m}^{-2} \mathrm{~d}^{-1}$ compared to $0.04 \pm 0.02 \mathrm{gC} \mathrm{m}^{-2} \mathrm{~d}^{-1}$ in the very fine sand. In winter, $P_{n}$ was also higher in the coarse sand than in the very fine sand with means of $0.06 \pm 0.02 \mathrm{gC} \mathrm{m}^{-2} \mathrm{~d}^{-1}$ and $-0.03 \pm 0.03 \mathrm{gC} \mathrm{m}^{-2} \mathrm{~d}^{-1}$ respectively

\section{Chlorophyll and phaeopigments}

Results from total chlorophyll measurements in lagoon sediments showed no significant difference between concentrations in consecutive summers (ANOVA, $F=0.15$ (VFS), and $F=0.23(\mathrm{CS})$; $\mathrm{df}=1 / 10$ ) or winters within sediment types $(F=0.20$ (VFS) and $F=0.96(C S) ; d f=1 / 10)$. Also, although there appeared to be a slight increase in mean chlorophyll concentrations in winter, the difference was not significant $(F=3.26 ;$ df $=1 / 22)$. Summer means were $5.8 \pm 1.8$ and $4.4 \pm 0.7 \mu \mathrm{g} \mathrm{chl} \mathrm{cm}{ }^{-3}$ (VFS) compared to $6.5 \pm 1.2$ and $5.06 \pm 0.53 \mu \mathrm{g} \mathrm{chl} \mathrm{cm} \mathrm{cm}^{-3}$ respectively in winter. Coarse sand generally gave higher chlorophyll

Table 4. F-values and degrees of freedom derived by a 3-way analysis of variance (ANOVA) of community production, $P / R$ ratios and respiration values from lagoon sediments in One Tree Lagoon

\begin{tabular}{|lccrrr|}
\hline & & \multicolumn{4}{c|}{$\mathrm{F}_{\text {-values }}$} \\
Interaction & $\mathrm{df}$ & $\mathrm{P} / \mathrm{R}$ & \multicolumn{1}{c|}{$\mathrm{P}_{\mathrm{g}}$} & $\mathrm{P}_{\mathrm{n}}$ & $\mathrm{R}_{\mathrm{g}}$ \\
\hline Among sediments & $1 / 4$ & 2.92 & 13.13 & 7.45 & 19.16 \\
Among years & $4 / 6$ & 0.31 & 0.54 & 0.28 & 0.79 \\
Among seasons & $6 / 24$ & 7.27 & 27.75 & 11.65 & 12.12 \\
\hline
\end{tabular}




\section{C.SAND}

a
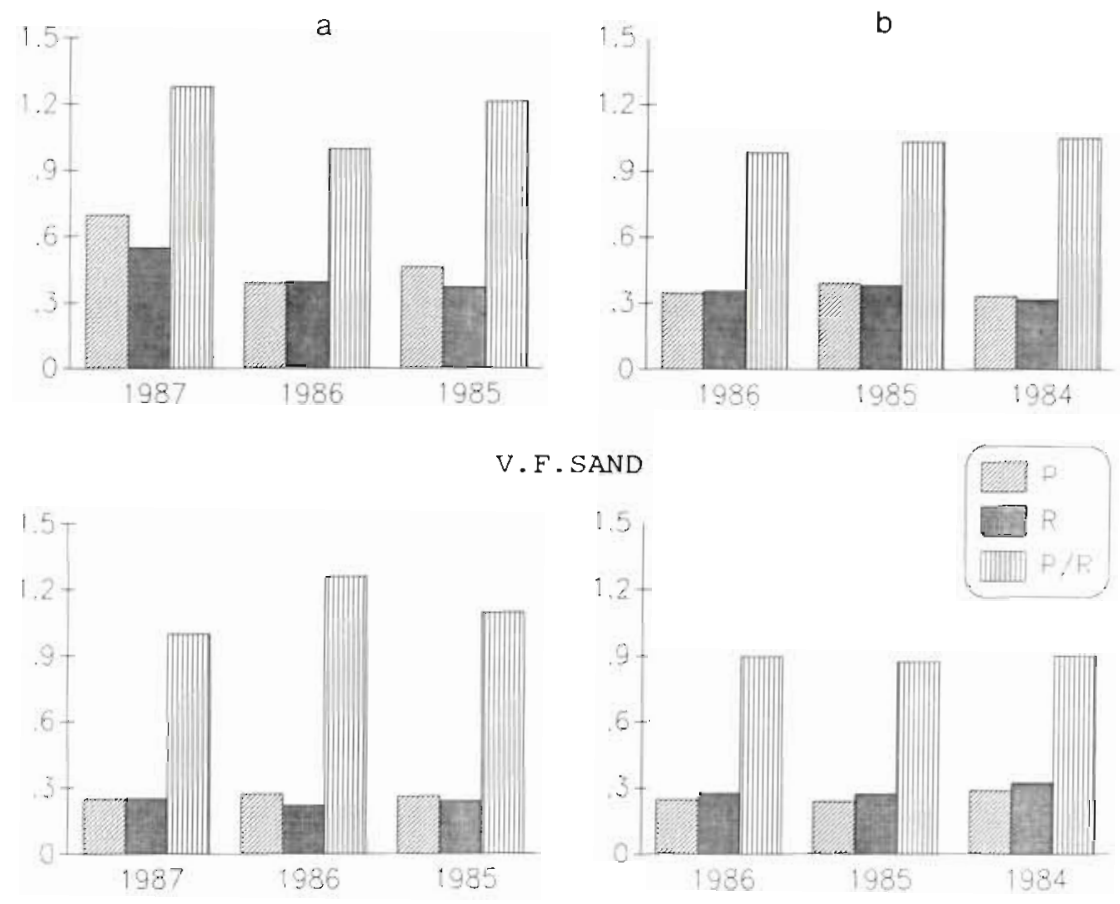

V.F.SAND

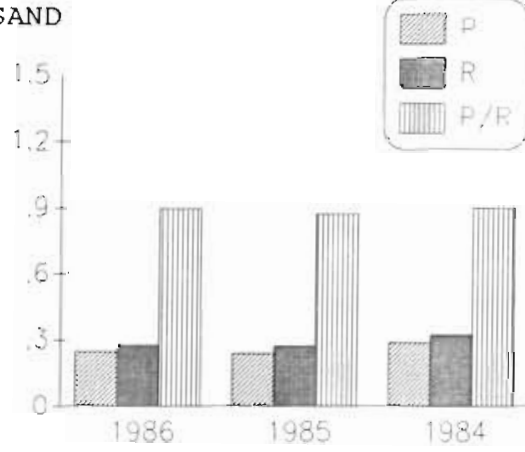

Fig. 5. Community production (P), community respiration $(\mathrm{R})$, and $\mathrm{P} / \mathrm{R}$ ratios over 3 consecutive years for coarse and very fine sediment types in One Tree Lagoon. (a) Summer values; (b) winter values concentrations than very fine sand but this difference was not significant in either summer or winter. On an areal basis, these values convert to a range of 44 to

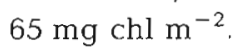

Phaeophytin concentrations were typically between 3 and $4 \%$ of the total chlorophyll concentration found in each sediment type. In summer, values ranged from $0.20 \pm 0.05 \mu \mathrm{g}$ phaeo. $\mathrm{cm}^{-3}$ in the coarse sand to $0.17 \pm 0.02 \mu \mathrm{g}$ phaeo. $\mathrm{cm}^{-3}$ respectively in the very fine sand, and in winter, from $0.26 \pm 0.03$ to $0.19 \pm 0.05 \mu \mathrm{g}$ phaeo. $\mathrm{cm}^{-3}$ respectively.

\section{Bacterial abundance in lagoon sediments}

In summer there were significantly more bacteria in the coarse sand than in the very fine sand (ANOVA, $F=25.56$ (summer); $\mathrm{df}=1 / 18$ ) but there was no significant difference between bacterial numbers in the coarse sand and very fine sand in winter. Within each sediment type, however, there were significant differences between bacterial numbers in winter and summer.

Further, in summer, mean counts were $3.47 \pm 1.43 \times$ $10^{8}$ cells $\mathrm{g}^{-1} \mathrm{dry}$ wt in the very fine, and $5.85 \pm 0.41 \times$ $10^{8}$ cells $\mathrm{g}^{-1}$ dry $\mathrm{wt}$ in the coarse sand. This compares with $10.26 \pm 2.95 \times 10^{8}$ and $13.73 \pm 4.1 \times 10^{8}$ cells g $^{-1}$ dry wt in the very fine and coarse sands in winter respectively. A study by Dr J. Hansen (pers. comm.) 12 mo later at a site nearer the reef crest than our coarse sand site showed a similar increase in bacterial numbers in the sediment; a range of 5.9 to $8.5 \times 10^{8}$ cells $\mathrm{g}^{-1}$ dry wt in summer compared to 23.1 to $26.2 \times$ $10^{8}$ cells $g^{-1}$ dry wt in winter.

\section{DISCUSSION}

A major aim of the present and related work (Johnstone et al. 1988) has been to understand the biological processes taking place in the sediments of a coral reef lagoon. In particular, it has been shown that a large amount of organic matter is deposited on the lagoon sediments every day (Koop \& Larkum 1987) and it is of great interest to know how this organic matter is recycled. Here we have analyzed the physical parameters of the sediments and the exchange of oxygen across the sediment surface in relation to the recycling processes.

A major conclusion from the present work is that the large input of detrital organic matter of $1.5 \mathrm{gC} \mathrm{m}^{-2} \mathrm{~d}^{-1}$ (fine sand site) and $2.3 \mathrm{gC} \mathrm{m}^{-2} \mathrm{~d}^{-1}$ (coarse sand site) does not accumulate in the sediments; as shown in Table 2 the total organic carbon in the sediments remains remarkably constant with season. All of this deposited material, thus, is recycled on and within the sediments. Further, the consistent concentrations of TOC at all depths sampled suggest a rapid mixing of the detrital material within the upper layers of the sediment. The lagoon sediments are fairly mobile. Storms and tidal currents contribute strongly to mixing processes (Frith 1985). In addition there is a large 
faunal component. Reworking of sediments is carried out by bottom-feeding fish (e.g. emperor fish), burrowing fish (e.g. gobies), holothurians, callianassid shrimps and a number of other bottom-living animals.

The high numbers of bacteria found within the sediments reflect their important role in the recycling processes. Microfaunal processing, however, may also occur (Hansen et al. 1987) and macrofauna such as holothurians (Moriarty 1982, Moriarty et al. 1985) and deposit-feeding gastropods (Hansen \& Skilleter pers. comm.) may also play a role in some areas. Whilst there have been few studies of benthic fauna at One Tree Reef (see for example Jones et al. 1990, St. John et al. 1990) the abundance of deposit-feeding organisms in the lagoon sediments would suggest that they are capable of removing an amount of organic material equivalent to that deposited on the lagoon sediments. Holothurians, for example, have been shown to be active deposit feeders which can consume significant quantities of sediment organic matter and bacterial biomass (Moriarty 1982). Further, feeding by crustaceans such as Callianassa spp., which are also widespread in One Tree lagoon, has been shown to be significant enough to negatively influence sediment microbial and meiofaunal communities (Hansen et al. 1987).

The physical parameters established in the present work for sediments in One Tree lagoon set the limits under which the detrital processing must occur. Since the oxygen concentration drops to zero within a depth of $5 \mathrm{~mm}$ in nearly all sediments, it is clear that anaerobic processes must predominate. It is also of great significance that the redox potential of the sediments changed from largely oxidizing (up to $+180 \mathrm{mV}$ ) in the winter to largely reducing (down to $-175 \mathrm{mV}$ ) in the summer. Such a seasonal response may be brought about by the higher activity of anaerobic bacteria in the higher temperature of the summer. If this is so it is not accompanied by any significant increase in the breakdown of organic matter in the summer (Table 2). The redox potentials of the sediments were similar to those found for sediments in the back reef studied by Williams et al. (1985). These potentials set the limits for the various biogeochemical processes in the sediments (Billen 1976). Under the observed potentials for One Tree Reef, neither hydrogen sulphide nor methane production would be expected in the winter, while some hydrogen sulphide production might be expected in the summer. This is consistent with a strong smell of hydrogen sulphide from some sediments in the summer and the lack of any evidence of methane in extensive measurements of sediment gases using gas chromatography for nitrogen fixation studies (Larkum et al. 1988, Larkum unpubl.). On the other hand, the redox potentials found in the sediments are certainly in the range where remineralisation of nitrogen can take place and the presence of ammonium at concentrations of 10 to $18 \mu \mathrm{mol} \mathrm{l^{-1 }}$ (Johnstone et al. 1988) indicates that ammonifications does take place.

In terms of nitrogen, the detritus 'rain' is capable of supplying between 136 and $272 \mathrm{mgN} \mathrm{m}^{-2} \mathrm{~d}^{-1}$ (Koop \& Larkum 1987). This input may well meet the demands of bacterial production and primary production and will be the subject of a later communication (Johnstone, Koop \& Larkum unpubl.). For the present it can be observed that the levels of nitrogen in the sediments are high, with $\mathrm{C}: \mathrm{N}$ ratios of 4.5 to 5.9 (cf. Entsch et al. 1983, Hansen et al. 1987), and remain seasonally stable. Thus nitrogen must also be turned over at a rate equal to the input rate from detrital deposition.

The oxygen experiments employing domes over the sediment were used to investigate the role of primary producers at the sediment/water interface. Such a method is only valid if primary production in the water column is not significant. Experiments on water column oxygen production in the light gave rates of less than $0.1 \mu \mathrm{mol} \mathrm{l}^{-1} \mathrm{~h}^{-1}$ (Johnstone 1989, Larkum unpubl.). Thus for the domes (36 l volume), the maximum oxygen production from this source would be $3.6 \mu \mathrm{mol} \mathrm{O}_{2} 1^{-1}$ $\mathrm{h}^{-1}$ which is insignificant compared with the observed rates of 3 to $4 \mathrm{mmol} \mathrm{O}_{2} \mathrm{~h}^{-1}$. Net photosynthesis was derived by subtracting community respiration from gross community photosynthesis (P). For benthic reef algae respiration is generally about one tenth the rate of gross photosynthesis (Downton et al. 1976). Thus in this study, where the rates of respiration were about one half of $\mathrm{P}$ (i.e. a $\mathrm{P} / \mathrm{R}$ ratio near unity; cf. Kinsey 1972), the heterotrophic component of respiration must have represented about $80 \%$ of the total. Based on these values and Eq. (1), the actual primary production on the lagoon sediments can be estimated by subtracting only the respiration due to primary producers (i.e. $10 \%$ of the total). This then gives net primary production values of between 0.57 and $1.71 \mathrm{gC} \mathrm{m}^{-2} \mathrm{~d}^{-1}$. As shown in Table 5 , the mean net primary production rate for the lagoon floor at One Tree Reef is low compared with other reefal communities. Such low rates are, however, comparable to those found elsewhere (Plante-Cuney 1973, Sournia 1976). Assuming a C:N ratio of 11 for algal primary producers (Koop \& Larkum 1987), many of which are blue-green algae (unpubl. obs.), the supply of nitrogen needed by these algae is 18 to $39 \mathrm{mgN} \mathrm{m}^{-2} \mathrm{~d}^{-1}$ in winter and 26 to $70 \mathrm{mgN} \mathrm{m}^{-2}$ $\mathrm{d}^{-1}$ in summer. The ammonium supplied by ammonification of the detritus in the deeper sediments is likely to be sufficient to meet the $\mathrm{N}$ requirements of the primary producers. This amount of nitrogen represents only 13 to $25 \%$ of the nitrogen input from sedimentation. In addition, nitrogen fixation occurs at a rate of 
Table 5. Area and mean net production rates $\left(P_{n}\right)$ for the main habitats on One Tree Reef. Total production values $\left(P_{t}\right)$ are calculated according to the total viable surface area in each habitat, and the production rate given for the sediments is from the present study. All other data come from Koop \& Larkum (in press)

\begin{tabular}{|lrrrr|}
\hline Habitat & Area (ha) & Area (\%) & $\begin{array}{c}\mathrm{P}_{\mathrm{n}} \\
\left(\mathrm{gC} \mathrm{m}^{-2} \mathrm{~d}^{-1}\right)\end{array}\left(\mathrm{kgC} \mathrm{d}^{-1}\right)$ \\
\hline Reef slope & 150 & 15 & 1.8 & 2700 \\
Reef crest & 60 & 5 & 2.0 & 1200 \\
Reef flat & 306 & 25 & 2.3 & 7040 \\
Patch reefs & 180 & 12 & 3.0 & 5400 \\
Beach rock & 90 & 6 & 1.0 & 900 \\
Lagoon & 370 & 37 & 0.1 & 370 \\
$\quad$ sediment & & & & \\
\hline
\end{tabular}

between 0.5 and $1.0 \mathrm{mgN} \mathrm{m}^{-2} \mathrm{~d}^{-1}$ in the (blue-green) algae on the lagoon floor (Larkum et al. 1988), which would offset the total by between 0.7 and $5.5 \%$.

In general, seasonality played a small part in the processes studied here. Lower temperatures in the winter may be responsible for the lower oxygen exchange and shorter days certainly decreased the primary production in winter. Year-to-year differences were also small but did occur (e.g. coarse sand in summer; Fig. 5). Considerable differences were observed between different sediment types. Not surprisingly oxygen penetrated further into the coarse sand. Coarse sand, however, also had the highest photosynthesis and primary production. This may be related to factors such as the greater penetration of light in the coarse sand.

Acknowledgements. We gratefully acknowledge the field support given to us by Philip Smith and Penny Butcher, the caretakers of One Tree Island field station, and the invaluable support from Dr Judy Hansen. We also express our gratitude for the funding provided by the Great Barrier Reef Marine Park Authority Linnean Society of N.S.W. (R.W.J.), by the Marine Science and Technologies grant scheme (A.W.D.L.) and by the Swedish Natural Sciences Research Council (Grants R-RA 8491-100 and R-RA 8491-105 to K. K.).

\section{LITERATURE CITED}

Alongi, D. M. (1986). Population structure and trophic composition of the freeliving nematodes inhabiting carbonate sands of Davies Reef, Great Barrier Reef. Aust. J. mar. Freshwat. Res. 37: 609-619

Billen, G. (1976). The dependence of the various kinds of microbial metabolism on the redox state of the medium. In: Biogeochemistry of estuarine sediments. Proc. UNESCO/ SCOR Workshop, Belgium. UNESCO, Paris, p. 254-261

Downton, W. J. S., Bishop, D. G., Larkum A. W. D., Osmond, C. B. (1976). Oxygen inhibition of photosynthetic oxygen evolution in marine plants. Aust. J. Plant Phys. 3: 73-79

Entsch. B., Boto, K. G., Sim, R. G., Wellington, J. T. (1983).
Phosphorous and nitrogen in coral reef sediments. Limnol. Oceanogr. 28: 465-476

Frith, C. A. (1983). Some aspects of lagoon sedimentation and circulation at One Tree Reef, Southern Great Barrier Reef. BMR J. Aust. Geol. Geophys. 8: 211-221

Frith, C. A. (1985). Lagoon circulation at One Tree Reef, southern Great Barrier Reef. Ph. D. thesis, The University of Sydney, Australia

Gray, J. S. (1981). The ecology of marine sediments. Cambridge University Press, Cambridge, U.K.

Hansen, J. A., Alongi, D. M., Moriarty, D. J. W. and Pollard, P. C. (1987). The dynamics of benthic microbial communities at Davies Reef, central Great Barrier Reef. Coral Reefs 6 : $63-70$

Hobbie, J. E., Daley, R. J., Jasper, S. (1977). Use of nuclepore filters for counting bacteria by fluorescence microscopy. Appl. environ. Microbiol. 33: 1225-1228

Johnstone, R. W (1989). Mineralization in coral reef lagoon sediments. Ph. D. thesis, The University of Sydney, Australia

Johnstone, R. W., Koop, K., Larkum, A. W. D. (1988). Fluxes of inorganic nitrogen between sediments and water in a coral reef lagoon. Proc. Linn. Soc. N.S.W. 110 (3): 219-227

Jones, G. P., Ferrell, D. J., Sale, P. F. (1990). Spatial abundance and structure of mollusc populations in the soft sediments of a coral reef lagoon. Mar. Ecol. Prog. Ser. 62: 109-120

Kinsey, D. W. (1972). Preliminary observations on community metabolism and primary productivity of the pseudo-atoll reef at One Tree Island, Great Barrier Reef. Proc. Symp. Corals and Coral Reefs, Mar. Biol. Ass. India, Cochin, India, p. 13-32

Kinsey, D. W. (1977). Seasonality and zonation in coral reef productivity and calcification. Proc. 3rd int. coral Reef Symp., Manila 383-388

Kinsey, D. W. (1978). Productivity and calcification estimates using slack water periods and field enclosures. In: Stoddart, D. R., Johannes, R. E. (eds.) Coral reefs: research methods. UNESCO, Paris, p. 439-468

Kinsey, D. W. (1979). Carbon turnover and accumulation by coral reefs. Ph. D. thesis, University of Hawaii

Kinsey, D. W. (1983). Standards of performance in coral reef primary production and carbon turnover. In: Barnes, D. J (ed.) Perspectives on coral reefs. Brian Clouston Publishing, A.C.T., Australia, p. 209-220

Koop, K., Larkum, A. W. D. (1987). Deposition of organic material in a coral reef lagoon, One Tree Island, Great Barrier Reef. Estuar. coast. Shelf Sci. 25: 1-9

Koop, K., Larkum, A. W. D. (in press). Quantitative significance of nitrogen fixation tor primary production on a coral reef, One Tree Island, Great Barrier Reef. Pubbl. Staz. zool. Napoli (I. Mar. Ecol.)

Larkum, A. W. D., Kennedy, I. R., Muller, W. J. (1988). Nitrogen fixation on a coral reef. Mar. Biol. 98: 143-155

Moriarty, D. J. W. (1982). Feeding of Holothuria atria and Stichopus chloronotus on bacteria, organic carbon and organic nutrogen in sediments of the Great Barrier Reef. Aust. J. mar. Freshw. Rs. 33: 255-263

Moriarty, D. J. W., Pollard, P. C., Alongi, D. M., Wilkinson, C. R., Gray, J. S. (1985). Bacterial productivity and trophic relationships with consumers on a coral reef (Mecor 1). Proc. 5th int. coral Reef Congr., Tahiti 3: 457-462

Parsons, T. R., Maita, Y., Lalli, C. M. (1984). A manual of chemical and biological methods for seawater analysis. Pergamon Press, Sydney, Australia

Plante-Cuney, M. R. (1973). Recherches sur la production primaire benthique en milieu marin tropical. I. Variations de la production primaire et des teneurs en pigments 
photosynthétiques' sur quelques fonds sableux. Valeur des résultats obtenus par la méthode du ${ }^{14} \mathrm{C}$. Cah. O.R.S.T.O.M. Sér. Océanogr. 11: 317-348

Revsbech, N. P., Jörgensen, B. B. (1986). Microelectrodes: their use in microbial ecology. Adv. Microb. Ecol. 9: 293-348

Sandstrom, M. W., Tirendi, F., Nott, A. (1986). Direct determination of organic carbon in modern reef sediments and calcareous organisms after dissolution of carbonate. Mar. Geol. 70: 321-329

Smith, S. V. (1973). Carbon dioxide dynamics: a record of organic carbon production, respiration and calcification in the Eniwetok reef flat community. Limnol. Oceanogr. 18: $106-120$

Sorokin, Y. I. (1982). Periphytonic and benthic microflora on

This article was submitted to the editor the reef: Biomass and metabolic rates. Proc 4 th int. coral Reef Symp., Manila, 1981. 2: 443-447

Sournia, A. (1976). Primary production of sands in the lagoon of an atoll and the role of foraminiferan symbionts. Mar. Biol. 37: 29-32

St. John, J., Jones, G. P., Sale, P. F. (1990). The distribution and abundance of soft sediment meiofauna and a predatory goby in a coral reef lagoon. Coral Reefs 8: 51-57

Vooren, C. M. (1981). Photosynthetic rates of benthic algae from the deep coral reef of Curaçao. Aquat. Bot. 10: $143-154$

Williams, S. L., Gill, I. P. and Yarish, S. M. (1985). Nitrogen cycling in backreef sediments (St. Croix, U.S. Virgin Islands). Proc. 5th intern. coral Reef Congr., Tahiti 3: 389-394

Manuscript first received: August 28, 1989

Revised version accepted: June 12, 1990 